\title{
「海洋コンクリート構造物の防食指針 (案)」について
}

\author{
鉄筋コンクリート構造物の劣化に関する研究委員会
}

\section{1.はしがき}

現在，鉄筋コンクリート構造物の劣化に関する問題は 我が国のみならず諸外国においても大きな問題になりつ つある。特にコンクリート中の鋼材の腐食に関しては, 従来あまり問題がないと考えられてきたが, 近年, 我が 国においても海砂使用の問題や, 海洋コンクリート構造 物の計画が検討されるようになるに伴って, 重大な問題 であることが明らかになってきた。

しかし，この問題はセメントコンクリートの分野と電 気化学の分野の境界領域の問題であるため, 問題の解明 並びに対策について個別の検討がなされてきている。こ のため実際の構造物への適用を図る場合にどのような基 準で判断すればよいかを総合的な立場から見直し，より 実用的な形で両分野で得られた知見を統合することが望 まれていた。そこで日本コンクリート工学協会では, セ メントコンクリート及び電気化学のそれぞれの専門家か らなる「鉄筋コンクリ一ト構造物の劣化に関する研究委 員会」( 小林一輔委員長) を昭和 54 年 4 月に発足させ, コンクリート中の鋼材にとって非常に厳しい腐食環境で ある海洋コンクリート構造物を対象とした「海洋コンク リート構造物の防食指針 (案)」（以下，本指針（案）と いう）を作成することとした。

我が国において，既に亜鉛めっき鉄筋の使用に関して は，土木・建築両学会において指針が作られており，ま た，防錆剤に関しても JIS の制定が間近いが，これら の個々の防食方法の規格化が進められても, 実際にどの ようなケースにいずれの方法を採用すればよいかの判断 を下すことができない。そこで, 本指針 (案) では, 従 来から行われている高品質のコンクリートで鋼材を防食 する方法をも含めた種々の防食方法を対象とし, 防食条 件に応じて, 現時点において最も適当と考えられる防食 方法の選定とその適用が容易に行えるょう配慮してい る。
現在，本指針（案）はまだ審議中であるためその全文 を紹介することはできないが，その骨格が明らかとなっ たので，その概要をここに紹介する。なお，参考のため， 文末に現在我が国並びに諸外国において規格化されてい る関連規格を一覧表にして示す。

\section{2. 委員会の構成}

鉄筋コンクリート構造物の劣化に関する研究委員会は 表一1 に示すように, 本委員会と分科会から成ってい る。分科会は, コンクリート分科会, 腐食防食分科会, 情報分科会から成っており，本指針（案）の原案作成及 び情報提供活動を行っている。各分科会間の調整のため には各分科会の主査及び幹事を中心とした扡大主查幹事 会が設けられ，最終的な指針（案）の審議は本委員会で 行われている。なお, 委員会活動の一環として行われた 文献調査の結果の一部は「鉄筋コンクリート構造物の劣 化に関する文献要約及び抄録集（第 1 集）」及び「同（第 2 集)」として既にまとめられている。

\section{3.「海洋コンクリート構造物の防食指針 (案)」の概要}

\section{1 本指針 (案) の構成と適用範囲}

本指針（案）は表一2 に示された目次（案）のような 構成になっており, その主たる目的は海洋コンクリート 構造物のコンクリート中の鋼材の防食にある。このた め, 本指針 (案) は外力の算定, 構造計算, 構造細目な ど, 海洋コンクリート構造物そのものの設計や施工につ いては規定を設けず，それらの問題は今までに出されて いる示方書や基準を利用することを前提としている。

本指針（案）の適用対象として海洋コンクリート構造 物を取り上げたのは，主に次の理由からである。

1) コンクリート中の鋼材は, 塩分の混入等のない通 常の使用条件ではコンクリートの中性化等が生じない限 


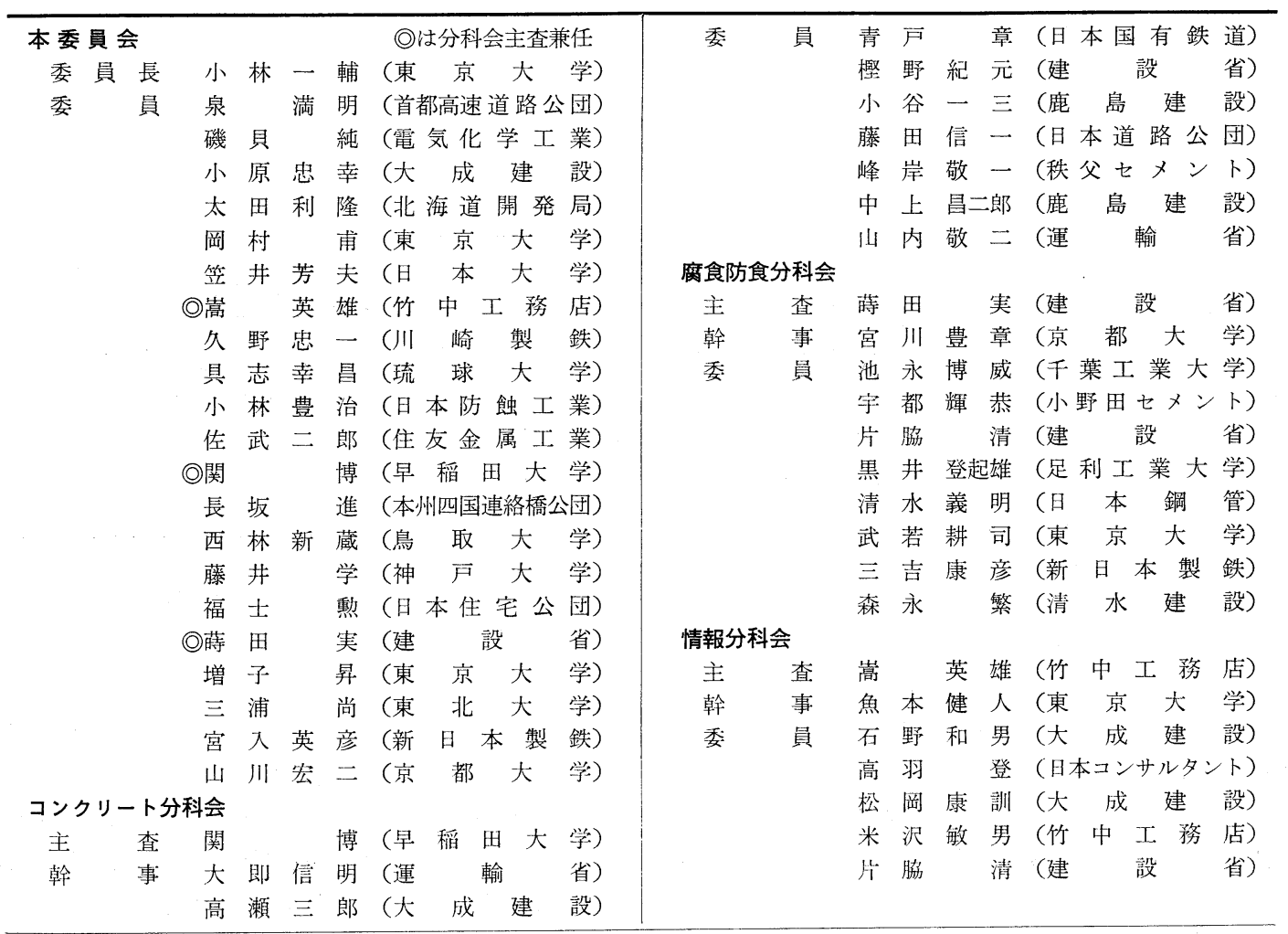

\section{表一2 海洋コンクリート構造物の防食指針（案）目次（案）}

\begin{tabular}{|c|c|c|c|}
\hline 第 1 章 & 総 & 3.2 & か ぶ り \\
\hline 1.1 & 適用範囲 & 3.3 & ひびわれ \\
\hline 1.2 & 用語の定義 & 3.4 & コンクリートの品質 \\
\hline 第 2 章 & 防食の基本 & 3.5 & コンクリートの施工 \\
\hline 2.1 & 防食の原則 & 第 4 章 & 第 2 種防食法 \\
\hline 2.2 & 防食の区分 & 4.1 & 第 2 種防食法の基本 \\
\hline 2.3 & 防食の適用 & 4.2 & 防食方法の分類と選定 \\
\hline 第 3 章 & 第 1 種防食法 & 4.3 & 防食方法 ～～～～ \\
\hline 3.1 & 第 1 種防食法の基本 & 第 5 章 & 検查 \\
\hline
\end{tabular}

り腐食しにくく，特別な対策を採用せずとも従来の方法 で対処し得ること。

2） 海砂の使用等によりコンクリート中に塩分が混入 される場合には, 塩分量の増大は起こらないため, 海洋 コンクリート構造物の場合のように外部から塩分の供給 が行われるより撖しい条件下における防食指針であれ ば，この問題をも包含できること。

3）化学薬品や迷走電流等によるコンクリート中の鋼 材腐食の問題は，その対象が限定されており一般的でな いこと。

これらのことから明らかなように本指針（案）は海洋 コンクリート構造物を対象とはしているものの, 従来建 設されている他の構造物に適用することは何ら問題がな
い。ただし，本指針（案）が対象としている海洋コン クリート構造物と比較してその防食条件の異なる構造 物に適用する場合には，その防食条件を考虑した上で 適用することが必要となる。

一般に海洋コンクリート構造物の耐久性について検 討を行う場合には, 主に次に示す 2 点について検討す る必要がある。

1）コンクリートの品質とその劣化

2) コンクリート中の鋼材の腐食

特に 2) が生ずると, 腐食生成物によって鋼材体積 が膨張し, コンクリートのひびわれの発生, かぶりコン クリートの剝離を招き, コンクリート中の鋼材の強度低 下，更には鋼材の破断が生ずるなど，構造物の耐久性上 重大な事態となる。しかし，1）のコンクリートの劣化 が生ずると 2）の鋼材の腐食が起こりやすくなるため, 両者を別々に論ずることはできない。以上の点を考慮 し，本指針（案）では 1）及び 2）の両者を包含した基 準を示すをのとし，コンクリートを鋼材の防食材料の一 つであると考えることとした。

このため, 本指針 (案) ではコンクリート中の鋼材の 防食方法を次に示す 2 つの方法に大別し, その適用方法 を規定することとした。

第 1 種防食法……鋼材の防食方法の中でコンクリート 
の防食性能のみで対処する方法

第 2 種防食法……鋼材の防食方法の中で第 1 種防食法 以外のより積極的な防食方法

以下に，表一2 の目次 (案) に従い，第 2 章から第 5 章までその概要を示す。

\section{$3.2 「$ 防食の基本」について}

\section{（1）防食の原則}

海洋コンクリート構造物の防食を検討するにあたって は，構造物が鋼材の腐食により所定の供用年限内にその 機能を損なうことのないように防食することが必要条件 となる。このためには，コンクリート中の鋼材に腐食を 生じさせないか, あるいは許容限度以下に抑制すること が必要であるが，現段階において許容し得る腐食度の具 体的な值は明確でなく，また，いったん鋼材に腐食を生 じ始めると, 海洋環境下においては腐食速度が加速度的 に大きくなるとされている。一方, 海洋コンクリート構 造物では，鋼材の腐食によりその機能を失うとその影響 が大きく，また補修も困難な場合が多い。そこで，本防 食指針（案）では，所定の供用年限の間に構造物を全く 補修しないことを前提とした。すなわち，その間にコン クリート中の鋼材に「腐食を生じさせないこと」を原則 とした。

\section{（2）防食の区分}

防食は, 所要の防食条件に基ゔいて，表一3 に示す $\mathrm{A}$ 種, $\mathrm{B}$ 種, $\mathrm{C}$ 種に区分することとし，防食にあたって は，これらの区分のいずれが適当かを判断することとし た。

表一3のように区分したのは, 対象となる構造物の防 食条件が異なる場合には防食の必要度も異なるためであ って，より適切な防食が行えるよう配慮したのである。 この場合, 構造物全体で一うの区分とする必要はなく, 部材単位の変更や供用年数の違い, 補修の有無によって も区分の変更を行うことができる。なお，表一3 に示し た防食の区分では，構造物の供用年数を $30 \sim 50$ 年程度 とした。

\section{表一3 防食の区分}

\begin{tabular}{|c|c|}
\hline 種 別 & 義 \\
\hline A 種 & $\begin{array}{l}\text { 飛沫帯またはそれと同等な非常に厳しい環境条件下 } \\
\text { において, 半永久的な耐用年数を保証する防食。 }\end{array}$ \\
\hline B 種 & $\begin{array}{l}\text { 海上大気中またはそれと同等な厳しい環境条件下に } \\
\text { おいて, 半永久的な耐用年数を保証する防食。 }\end{array}$ \\
\hline C 種 & $\begin{array}{l}\text { 海中またはそれと同等な環境条件下において，半永 } \\
\text { 久的な耐用年数を保証する防食。 }\end{array}$ \\
\hline
\end{tabular}

\section{（3）防食の適用}

防食方法の選定にあたっては「防食の区分」に応じて

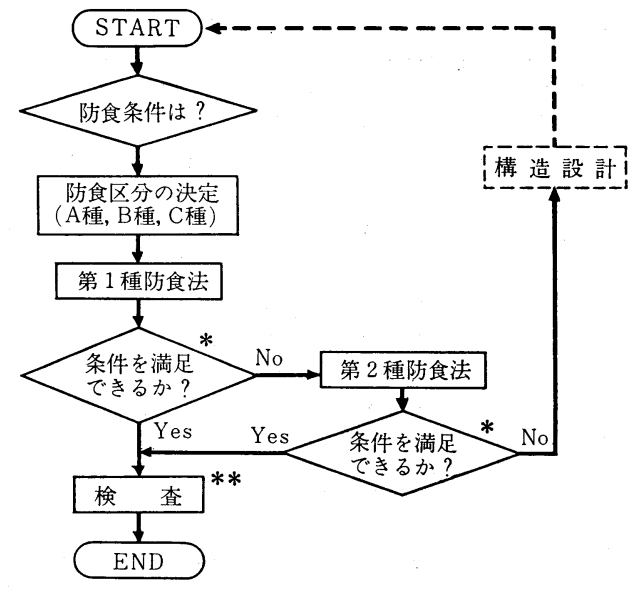

（注）＊の条件は防食区分( A種, B種, C種）によって異なる。 ** 検查は必ずしも必要ではない。 実線部は本指針(案)に示されているが, 破線部は示され ていない。

\section{図一1 本指針 (案) のフローチャート}

これを満足する防食方法を選定しなければならないが， 本指針(案)ではまず第 1 種防食法の適用について検討を 行い，その適用が困難な場合，あるいは更に防食性能を 増大させる場合には第 2 種防食法を用いることとした。

「防食の区分」に応じた防食方法を選定することは当 然のことであるが，その際まずコンクリートの耐久性を 考慮した第 1 種防食法を適用することを前提としたの は，コンクリートによる防食は最も確実な方法であり， 現在第 2 種防食法として提案, 実施されている方法に は，第 1 種防食法と併用して初めて有効となるものも多 いからである。このため, 第 1 種防食法の要件を完全に 満たすことができずに第 2 種防食法を適用する場合にお いても，第 1 種防食法の要件をできるだけ多く満足させ なければならない。

以上述べたことを図一1によとめて示す。なお図一1 から明らかなように，第 1 種防食法並びに第 2 種防食法 のいずれの場合にも，適用可能な範囲を越えた場合には 構造物の設計をやり直さなければならない。

\section{3 第 1 種防食法」について}

\section{（1）第 1 種防食法の基本}

第 1 種防食法とは，コンクリートの防食機能のみで内 部鋼材を防食するものであり，本指針（案）では，防食 区分に応じて適切なかぶり，ひびわれ条件を定め，適切 な品質のコンクリートを用い，更には適切な施工を行う ことによって内部鋼材を防食するものである。

腐食は非常に複雑な電気化学的反応に基づくものであ り, 理論上は $\mathrm{A}$ 種, $\mathrm{B}$ 種, $\mathrm{C}$ 種の各防食区分に対して, かぶり，ひびわれ幅，品質，施工などの要因が相互に関 
連する規定を設けることも可能であるが，定量的には無 理な面がある。そこで，ここでは，それぞれの要因に対

し独立に規定を設けることとした。

海洋コンクリート構造物 の施工条件は, 海上現場打 設, 海上ヤード打設（静穏な海域で管理された施工施設 がある)，陸上ヤード打設，及び工場打設（パイルなど） がある。これら 4 つの施工条件のうち一般には前 2 者, 特に海上現場打設の施工条件は厳しく，陸上ヤード及び 工場での打設は施工条件がよい。本指針（案）では，海 上現場打設に相当する施工条件を「施工条件の厳しい場 合」，陸上ヤード打設に相当するものを「施工条件のよ い場合」として防食設計に反映させることとした。

また，海上での施工条件は，陸上に比較して自然条件 を含めて過酷なものであり，しかも防食区分に応じて求 められる品質は一段と厳しい。そのため, 特別な配慮を しない限り，海上現場打設は避けることとした。

(2) か ぶり

第 1 種防食法では，防食区分に応じて適切な最小かぶ りを確保する必要があり，更に施工条件の良否，鉄筋コ ンクリート，プレストレストコンクリートの別について もその影響を考慮することとした。最小かぶりは，コン クリート内部にある組立鉄筋等をも含めた全鋼材を対象 とし、コンクリートの最小の被覆厚をとることにした。

\section{(3) ひびわれ}

第 1 種防食法では，防食区分及び荷重の頻度に応じて 適切な許容ひびわれ幅を設定する必要がある。

本指針（案）でいうひびわれ幅は，実用上コンクリー 卜表面のひびわれ幅を指すことにした。ひびわれ発生に は種々の原因があるが，設計時に考慮するひびわれは主 として荷重作用によるものであり，場合によっては乾燥 収縮, クリープ, 温度の影響も含めることになる。

大きなひびわれ幅を発生させる荷重の頻度が大きいほ ど腐食しやすいことは明らかである。従って，本指針で は荷重の頻度の影響もひびわれ幅許容値に反映させるこ ととした。

表面ひびわれ幅は，鋼材ひずみが同じ場合，かぶりが 大きいほど大きくなり，かぶりが小さいほど設計上は有 利となるため防食上矛盾を生ずる。これを考慮して, 最 小かぶり厚を増加させた場合, 表面ひびわれ幅の許容值 も増加してよいとした。

太径鉄筋 D 51 については，使用実績は少ないが， 特に区別しないこととした。

\section{（4）コンクリートの品質}

コンクリートが内部の鋼材に対して十分な防食機能を 有するためには，施工時のコンクリート中に有害量の腐 食物質を含有せず, かぶりコンクリートに部分的な欠陥 がなく均等質であり, 完成後も腐食物質の浸透に対して

Vol. 19, No. 3, March 1981
これを抑制する十分な水密性を有することが大切であ る。

上記の条件を満足するために，コンクリートの品質と して，防食の区分，施工条件（気象・海象を含む）など に最も適した材料を選定し，配合（調合）を定めなけれ ばならない。凍結融解作用を受ける地域の海面下を除い た部材では, 水セメント比や空気量に対する配慮が最も 重要である。一方, 温和な地域では, セメントの種類, 水セメント比やセメント量などに慎重な配慮が望まれ る。

\section{（5）コンクリートの施エ}

施工環境の厳しい海洋での工事は必要最小限とするの が原則であるが，大規模な海洋構造物では，部材の接合 など海洋工事が必要となることが予想される。この場 合，設計上考慮された基本的事項を忠実に満足させるた めには，施工環境ばかりでなく，使用材料の入手と運搬 方法，施工能力，労働条件などをあらかじめ調查検討 し，これに見合った作業手順による工程計画，労務計 画，資機材調達計画，あるいは品質管理等の計画を作成 し，これを遵守しなければならない。

特に注意しなければならない点を挙げると, 次のよう なものがある。

材料の貯蔵や運搬中に，波しぶきや海水の浸入が起こ りやすく，材料が劣化しやすいので配慮が必要となる。

厳しい自然条件下では，接合部は構造上はもとより防 食上も最大の弱点となりやすく, 飛沫帯や海中での部材 接合は極力避けた方がよいとした。

作業時間の短縮と施工精度を確保するために，容易に 組立て・解体作業のできるよう，例えば大型パネルの採 用などを検討する必要もある。

更に，コンクリートプラント船について，波浪による 動摇，衝撃，あるいは機械的振動などにより，計量装置 に過大な計量誤差が生じやすいので，性能，実績の十分 確認されたものを選定しなければならない。

\section{4 第 2 種防食法」について}

\section{（1）第 2 種防食法の基本}

第 2 種防食法は，第· 1 種防食法の要件を構造，材料， または環境条件などによってすべてを満足させることが できない場合，あるいは防食性をより高めようとする場 合に用いられる防食の方法である。従って，第 2 種防食 法が実際に適用される段階では，あらかじめ第 1 種防食 法が十分検討されなければならないことは当然である。 従って第 1 種防食法の要件をできるだけ多く満足させた 上で第 2 種防食法を適用しなければならない。

\section{（2）第 2 種防食法の分類亡選定}

第 2 種防食法は, その作用機構によって, 表一4 に示 


\begin{tabular}{|c|c|c|c|c|c|}
\hline 作 & 用 & 機＼cjkstart構 & \multicolumn{2}{|c|}{ 具 体 的 方 法 } & 例 \\
\hline \multirow{3}{*}{\multicolumn{3}{|c|}{$\begin{array}{l}\text { 鋼材表面を腐食環境から遮断する } \\
\text { ことにより，塩化物を代表とする } \\
\text { 腐食性成分の漫透を制御する方法 }\end{array}$}} & \multirow{2}{*}{$\begin{array}{l}\text { コンクリート } \\
\text { 層において浸 } \\
\text { 透を制御す } \\
\text { る。 }\end{array}$} & $\begin{array}{l}\text { コンクリート層の漫透 } \\
\text { 性を低下させる。 }\end{array}$ & $\begin{array}{l}\text { ライニング (メンプレン, コー } \\
\text { ティング), ホホリマーコンクリ } \\
\text { トト(PCI, PCC), ワクンーコ } \\
\text { ンクリート, あまに油処理 }\end{array}$ \\
\hline & & & & $\begin{array}{l}\text { コンクリートに生じた } \\
\text { ひびわれに補修材を注 } \\
\text { 入し, ひびわからの } \\
\text { 漫透を防止する。 }\end{array}$ & セメント系, 樹脂系 \\
\hline & & & $\begin{array}{l}\text { 鋼材に表面処瑅 } \\
\text { 材表面への浸 }\end{array}$ & $\begin{array}{l}\text { 里を施すことにより，錄 } \\
\text { 季を制御する。 }\end{array}$ & 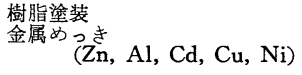 \\
\hline 腐食の原 & とな & コンクリート中 & $\begin{array}{l}\text { 腐食性を㧕制一 } \\
\text { る。 }\end{array}$ & トることによって処理す & 防 錆 剂 \\
\hline の環境を & 理す & 方法 & $\begin{array}{l}\text { 腐食性成分を } \\
\text { する。 }\end{array}$ & ロンクリート中から除去 & 電気泳動の応用 \\
\hline $\begin{array}{l}\text { 環境中の } \\
\text { を行わ }\end{array}$ & 食性 & 分に対して制御 & $\begin{array}{l}\text { 鋼材／腐食性女 } \\
\text { 世, 活性領域 } \\
\text { る。 }\end{array}$ & $\begin{array}{l}\text { 某体間の電位を変化さ } \\
\text { から人工的に 分極させ }\end{array}$ & 電気防食 \\
\hline & & & $\begin{array}{l}\text { 鋼材組成を改 } \\
\text { 腐食性に耐え }\end{array}$ & $\begin{array}{l}\text { 多し，コンクリート中の } \\
\text { 材料とする。 }\end{array}$ & 耐 塩 性 鋼 \\
\hline
\end{tabular}

待するために，ある種の防食方 法については 2 種類以上の方法 を組み合わせて適用することを 推奨している。

\section{（3）防食方法}

図一2 で示した防食方法につ いて, 適用範囲, 材料の種類と 品質, 施工上の留意点, 品質管 理のための検查などの項目を検 討中であるが，主な内容は次の と抒りである。

(a) ライニング

新設及び既設の構造物に適用 できるが，海中では施工が困難 であり，かつ海中の生物付着に よるライニング層の剝離の可能

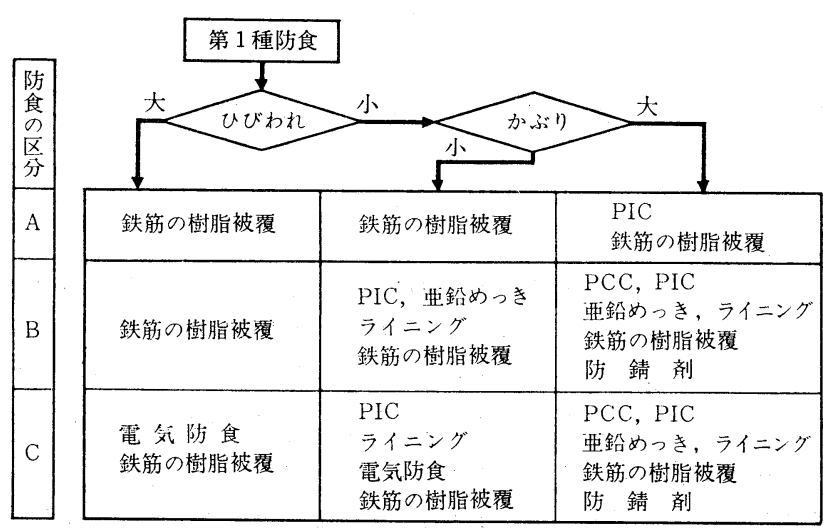

（注） PIC：ポリマー食浸コンクリート PCC：ポリマーセメントコンクリート

\section{図一2 第 2 種防食法の選定方法の防食区分との関係}

すように分類することができる。対象としている構造物 に最適な第 2 種防食法をこれらの中から選定するには， 第 1 種防食法で満たされている要件と防食方法の防食機 構及び特徵を考慮した上で, 部材の防食区分に従って選 定することが必要である。

そこで本指針（案）では，第 1 種防食法の要件のうち 特に重要なひびわれ幅とかぶり厚の大小並びに防食区分 に応じて, 防食性能上有效と考えられる第 2 種防食方法 を図一2 のように示した。適切な防食方法が複数示して ある場合には，施工法と経済性を考慮して実施が可能な ものを選ぶことになる。ここに示したひびわれ幅とかぶ り厚は，第 1 種防食法で規定されているものを指す。な お，第 2 種防食法による構造物の耐用年数は一応 30 年 を想定しているが，いずれの防食方法も実験研究の数に 比べて海洋構造物への実施例が少ないため, 更に実施例 の収集と検討を行っている。また，より高い防食性を期
性を考慮すると，その適用は海上大気中に限ら れる。

ライニングにはシートを用いる方法と塗膜に よる方法があるが，膜厚をかなり厚くして，材 質は高分子材料を 2 種以上混合して変性したも の，またはガラス綫維で補強したものとする。 また，下地やシートの継ぎ目の処理や施工時の ピンホールの除去を完全に行わなければならな い。

（b） ポリマー含浸コンクリート（PIC）

新設の構造物で, 特にプレキャストコンクリ 一トや場所打ちコンクリート構造物の水平部材 などに適しており, すべての海洋環境下で使用 できるが，ひびわれが小さいことが条件であ る。

モノマーは液状のビニル系樹脂を主成分に用い，十分 な防錆効果が得られるように適切な含浸深さ，含浸方法 及び重合方法を定める。

（c） ポリマーセメントコンクリート（PCC）

新設の構造物についてすべての海洋環境下で適用でき るが，ひびわれが小さいことが条件である。

セメント混和用ポリマーディスパージョンは合成ゴム ラテックスを用い，ポリマーセメント比は 15〜25\% を 標準として，コンクリートの養生方法と養生日数は予備 試験により定める。

(d) 樹脂塗装鉄筋

すべての海洋環境下で鉄筋コンクリート構造物を新設 する場合に使用できるが，プレストレストコンクリート には使用できない。

樹脂塗装鉄筋は粉体型エポキシ塗料を用い，静電粉体 塗装により作製し，塗装膜厚は $180 \pm 5 \mu \mathrm{m}$ とする。 
鋼材を樹脂塗装する防食方法は比較的新しく開発され た方法で, 海洋構造物に対する使用施工例はまだない が, 国内及び海外で多数の室内・屋外試験によって品質 や性能の良さが確かめられており，ひびわれやかぶり厚 の大小の影響を受けにくいという利点がある。従って, 本指針 (案) では, かなり厳しい環境下でも防食効果が 十分期待できる方法として取り扱っている。

(e) 亜鉛めっき鉄筋

プレストレストコンクリートを除いた鉄筋コンクリー ト構造物を新設する場合に使用できるが，亜鉛めっき鉄 筋を用いたコンクリート構造物の耐食性はコンクリート の品質や施工の良否に大きく影響されるので, 適用範囲 が限定される。本指針（案）ではコンクリートが劣化さ れやすい飛沫帯を除く海洋環境下で適用できることとし た。

\section{(f) 電気防食}

新設及び既設のいずれの構造物にも適用できるが，コ ンクリートが湿潤状態にあることが条件で, 主に海中部 分に適している。

電気防食の方法は陰極防食とし, 外部電源法あるいは 流電陽極法を用いる。また防食電位は（-0.77〜-0.85） $V$ (銅硫酸銅電極基準) の範囲とする。

（g）防錆剂

洋上大気中で海塩粒子の影響が少ない環境条件に新設 する構造物に適用できる。

コンクリート用防錆剤はもともと海砂に対する鉄筋の 防錆処置として考案されたものであり，綮しい海洋環境 下で他の防食法と同等の防食性を期待するのは困難であ り，他の防食方法との併用を前提として取り扱ってい る。

\section{5 「検査」について}

本指針（案）における第 1 種防食法, 第 2 種防食法あ るいは両者を適用して建造された構造物は, 本来, 半永 久的な供用が保障されている。しかし，本指針（案）に よる防食を行わなかった既往の構造物, あるいは劣化が 生じているような構造物に対しては, コンクリート中の 鋼材腐食に関わる種々の検査を行う必要がある。更に, 本指針（案）によって建造された構造物ではあっても， 本指針（案）の防食法の効果を確認するため，あるいは 維持・補修の上からも, 種々の検査手法が確立されるこ とが望ましい。

実在の構造物における腐食機構は多くの要因によって 構成されており，検查結果の一意的な解釈は困難であ り, 解析は複雑である。そのため, 主要な要因を取り出 して室内において試験を行い, 現実における腐食問題を 検討することが必要である。そのためには, 広く一般に

Vol. 19, No. 3, March 1981
用いることができる標準的な試験方法が必要である。

以上の考え方より，本指針（案）においては，第 5 章 「検查」を設け, 種々の要因の測定手法を中心として示 すこととした。なお，第 2 種防食法の各項目に必要な検 查手法についてはここでは省略した。

\section{4. 参考となる各国の基準・規格類}

\section{1 公的規格}

海洋コンクリート構造物の代表的規格の中から, 耐久 性に関する要因を主に表一5 にまとめた。なお, コンク リート船舶については，ソ連（船級登録局制定）及び FIP の規格があるが，現在審議中の本指針(案)とは性格 がいささか異なるので，本表からは除外している。

\section{2 第 2 種防食法を主対象とする規格類}

表一6 には，本指針 (案) 第 4 章「第 2 種防食法」に 関係のある規格類を紹介した。研究の急速な進展に伴 い，第 2 種防食法に関する規格は順次整備されている段 階であることから, 現在 (昭和 55 年 12 月) の時点で 草案のものまでも含めた。

\section{3 指 針 類}

鉄筋コンクリートの耐久性と関連する指針類を以下に 紹介する。

1）無筋および鉄筋コンクリート標準示方書（土木学 会)

2) 建築工事標準仕様書・同解説 (日本建築学会)

3) Durability of Concrete in Service, 1962 (ACI)

4) Guide to Durable Concrete, 1977 (ACI)

5) Guide for Repair of Concrete Bridge Surface, 1980 (ACI)

なお，以上の規格指針類の収集及びとりまとめは，情 報分科会 (嵩英雄主査) が主体となって行ったものであ る。

\section{5.あとがき}

「海洋コンクリート構造物の防食指針（案）」は，昭和 57 年 3 月を目標に検討を行っており, 今後更に詳細な 審議が行われる予定である。本文で紹介した内容につい てもいまだ確定したものではないので, 最終的に完成し た指針（案）と異なる部分もあり得ると考えられるが, その点についてはご容赦願いたい。

（文責 : 魚本, 大即, 池永, 宮川, 片脇） 
表一5 海洋コンクリート構造物

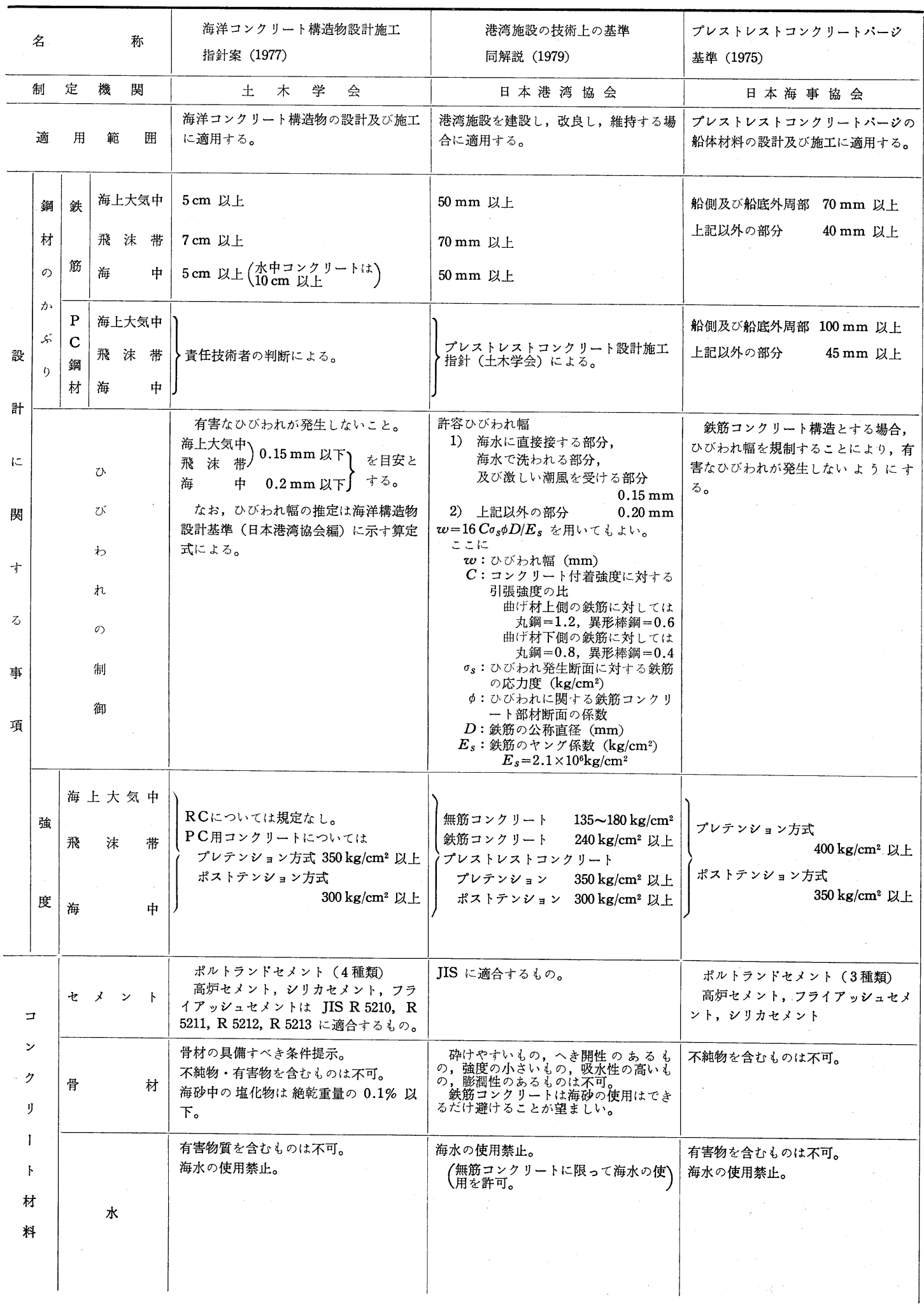


（注）単位はメートル法に換算した。

$\mathrm{RC}$ ：鉄筋コンクリート

PC：プレストレストコンクリート

\begin{tabular}{|c|c|c|c|c|c|c|c|c|}
\hline \multicolumn{2}{|c|}{$\begin{array}{l}\text { Guide for the Design and } \\
\text { Construction of Fixed } \\
\text { Offshore Concrete Struc- } \\
\text { tures (1978) }\end{array}$} & \multicolumn{2}{|c|}{$\begin{array}{l}\text { Recommendation for the } \\
\text { Design and Construction } \\
\text { of Concrete Sea Structures } \\
(1977)\end{array}$} & \multicolumn{3}{|c|}{$\begin{array}{l}\text { Rules and Regulations } \\
\text { for the Construction and } \\
\text { Classification of Off- } \\
\text { shore Platforms (1975) }\end{array}$} & $\begin{array}{l}\text { Rules for the Design, } \\
\text { Construction and Inspec- } \\
\text { tion of Offshore Structures } \\
\text { (1977) }\end{array}$ & $\begin{array}{l}\text { Guidelines for the Design, } \\
\text { Construction and Clas- } \\
\text { sification of Floating Con- } \\
\text { crete Structures (1978) }\end{array}$ \\
\hline \multicolumn{2}{|c|}{$\mathrm{ACI}$} & \multicolumn{2}{|c|}{ FIP } & \multicolumn{3}{|c|}{ BV } & DNV & DNV \\
\hline \multicolumn{2}{|c|}{$\begin{array}{l}\text { 鉄筋コンクリート及びプレス } \\
\text { トレストンリート製固定 } \\
\text { 式 (重力式) 海洋構造物の設 } \\
\text { 計及゙施工に適用寸る。 }\end{array}$} & \multicolumn{2}{|c|}{$\begin{array}{l}\text { 海洋コンクリート構造物の設 } \\
\text { 計及び施工に適用する。 }\end{array}$} & \multicolumn{3}{|c|}{$\begin{array}{l}\text { 鋼製及びコンクリート製沖 } \\
\text { 合プラットフォームの施工 } \\
\text { 及び船級指定に適用する。 }\end{array}$} & $\begin{array}{l}\text { 鋼製及びコンクリート製海洋 } \\
\text { 構造物に適用ナる。 }\end{array}$ & $\begin{array}{l}\text { 浮遊式コンクリート製構造物 } \\
\text { の設計・施工及び船級指定に } \\
\text { 適用する。 }\end{array}$ \\
\hline $\begin{array}{l}\text { 1) 㕌さ } \\
50 \mathrm{~cm} \text { 注上の } \\
\text { 部材 } \\
50 \mathrm{~mm} \text { 以上 } \\
65 \mathrm{~mm} \text { 以上 }\end{array}$ & \begin{tabular}{|l|} 
2) 厚さ \\
$50 \mathrm{~cm}$ 以下の部 \\
材 \\
左記の値を用 \\
なる。やを得 \\
ない場合は注2) \\
の項目の値 \\
をいる。 \\
\end{tabular} & \begin{tabular}{|} 
1) 壁厚 \\
$0.50 \mathrm{~m}$ 以上 \\
$75 \mathrm{~mm}$ 以上 \\
$75 \mathrm{~mm}$ 以上 \\
$60 \mathrm{~mm}$ 以上
\end{tabular} & \multirow[t]{2}{*}{$\left|\begin{array}{l}2) \text { 壁厚 } 0.50 \\
\mathrm{~m} \text { 以下 } \\
\text { 骨材最大寸法 } \\
\text { の } 1.5 \text { 倍以上か } \\
\text { つ最大鉄筋径の } \\
1.5 \text { 倍以上 }\end{array}\right|$} & \multicolumn{3}{|c|}{$\begin{array}{l}50 \mathrm{~mm} \text { 以上 } \\
\text { タイタル部として } \\
65 \mathrm{~mm} \text { 以上 } \\
50 \mathrm{~mm} \text { 以上 }\end{array}$} & $\begin{array}{l}40 \mathrm{~mm} \text { 以上 } \\
50 \mathrm{~mm} \text { 以上 } \\
50 \mathrm{~mm} \text { 以上更に骨材最大 } \\
\text { 寸法の } 1.5 \text { 倍 } \\
\text { 以上 }\end{array}$ & $\begin{array}{l}25 \mathrm{~mm} \text { 以上 } \\
40 \mathrm{~mm} \text { 以上 } \\
25 \mathrm{~mm} \text { 以上 }\end{array}$ \\
\hline $75 \mathrm{~mm}$ 以上 & $\begin{array}{l}\text { 注 2) の a), } \\
\text { b), c) の最大 } \\
\text { 値に } 13 \mathrm{~mm} を \\
\text { 加えたもの }\end{array}$ & $\begin{array}{l}100 \mathrm{~mm} \text { 以上 } \\
100 \mathrm{~mm} \text { 以上 } \\
75 \mathrm{~mm} \text { 以上 }\end{array}$ & & \multicolumn{3}{|c|}{$\begin{array}{l}\text { シースのかぶり } \\
75 \mathrm{~mm} \text { 以上 }\end{array}$} & 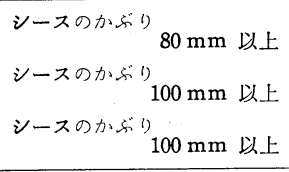 & $\begin{array}{l}\text { ンースのかぶり } 50 \mathrm{~mm} \text { 以上 } \\
\text { ンースのかぶり } 80 \mathrm{~mm} \text { 以上 } \\
\text { ンースのかぶり } 50 \mathrm{~mm} \text { 以上 } \\
\end{array}$ \\
\hline \multicolumn{2}{|c|}{$\begin{array}{l}\text { コンクリート面で引張応力 } \\
\text { が生ずる所の最小鉄筋量 } A_{s} \\
\text { を次式で規定。 } \\
A_{s}=\frac{f_{t}}{f_{y}} \cdot b \cdot d_{e} \\
\text { こに, } \\
f_{t}: \text { コンクリート平均引張 } \\
\text { 強度 } \\
f_{y}: \text { 鉄筋降伏点 } \\
b: \text { 断面の幅 } \\
d_{e}: 1.5 C+10 d_{b} \\
C: \text { コンクリートかム゙ } \\
d_{b}: \text { 鉄筋直径 } \\
0.2 h \leq d_{e}<0.5(h-x) \\
h: \text { 断面厚 } \\
x: \text { 压縮ゾーンの深さ }\end{array}$} & \multicolumn{2}{|c|}{ 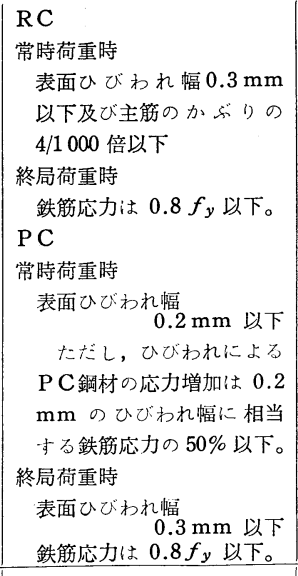 } & $\begin{array}{l}\text { 国際プ } \\
\text { 発行の } \\
\text { for the I } \\
\text { struction } \\
\text { Sea Str } \\
\text { る。 } \\
\end{array}$ & $\begin{array}{l}\text { ストレ } \\
\text { ecomme } \\
\text { esign ar } \\
\text { of } 0 \\
\text { ctures }\end{array}$ & $\begin{array}{l}\text { スト協会 } \\
\text { endation } \\
\text { nd Con- } \\
\text { Concrete } \\
\text { に準抛す }\end{array}$ & 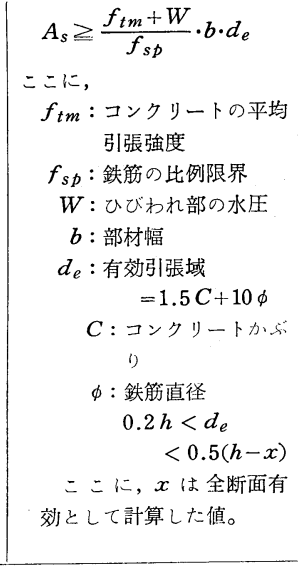 & $\begin{array}{c}A_{s} \geq \frac{f_{t m}+W}{f_{s p}} \cdot b \cdot d_{e} \\
=こ に, \\
f_{t m}: \text { コンクリートの平均 } \\
\text { 引張強度 } \\
W: \text { ひびわれ部の水圧 } \\
f_{s p}: \text { 鉄筋の比例限界 } \\
\quad\left(<f_{s y}\right) \\
b: \text { 部材幅 } \quad \\
d_{e}: \text { 有効引張域 } \\
\quad=1.5 C+10 \phi \\
C: \text { コンクリートかム } \\
\text { り } \\
\phi: \text { 鉄筋直畦 }\end{array}$ \\
\hline \multicolumn{2}{|c|}{$\begin{array}{l}352 \mathrm{~kg} / \mathrm{cm}^{2} \text { 以上 } \\
\text { 洗掘によるすりへりの恐れ } \\
\text { のある場合は } 422 \mathrm{~kg} / \mathrm{cm}^{2} \\
\text { 以上 }\end{array}$} & \multicolumn{2}{|c|}{$408 \mathrm{~kg} / \mathrm{cm}^{2}\left\{\begin{array}{r}\text { ただし海洋環境 } \\
\text { に直接さらされ } \\
\text { ないもの } \\
308 \mathrm{~kg} / \mathrm{cm}^{2} \\
306 \mathrm{~kg} / \mathrm{cm}^{2} \\
\text { 以上 } \\
\text { 以 } \\
\text { 厳しい洗掘作用 } \\
\text { を受ける場合は } \\
459 \mathrm{~kg} / \mathrm{cm}^{2} \\
\text { 以上 }\end{array}\right.$} & \multicolumn{3}{|c|}{$306 \mathrm{~kg} / \mathrm{cm}^{2}$ 以上 } & $\begin{array}{l}\text { RILEMによって行った } \\
\phi 15 \mathrm{~cm} \times 30 \mathrm{~cm} \text { での材令 } \\
28 \text { 日強度が基準となる。 } \\
\text { 材令 } 28 \text { 日以降で材令に } \\
\text { 伴う強度の伸びは考慮す } \\
\text { る。 } \\
\text { 材令 } 28 \text { 日以前で荷重を } \\
\text { 受けるときは実際の測定強 } \\
\text { 度による。 }\end{array}$ & 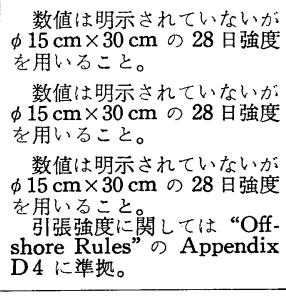 \\
\hline \multicolumn{2}{|c|}{$\begin{array}{l}\text { ポルトランドセメント（AS } \\
\text { TM-C 150, C } 595 \text { ) } \\
\mathrm{C}_{3} \mathrm{~A} \text { の含有量 : } 4 \text { 〜 } 10 \% \\
\text { 油槽に使用する ときは } \mathrm{C}_{3} \mathrm{~A} \\
\text { の減少を規定。 }\end{array}$} & \multicolumn{2}{|c|}{$\begin{array}{l}\text { ポルトラントセメント, 而 } \\
\text { 硫酸塩セメント, 混合セメン } \\
\text { トで各国規準に適合し， } \mathrm{C}_{3} \mathrm{~A} \\
\text { の含有量 } 12 \% \text { 以下のもの。 }\end{array}$} & \multicolumn{3}{|c|}{$\begin{array}{l}\text { フランス規格に合致するも } \\
\text { ので, } \mathrm{C}_{3} \mathrm{~A} \text { の含有量 } 8 \% \\
\text { 以下。 }\end{array}$} & $\begin{array}{l}\text { 普通, Modified, 速硬, 低 } \\
\text { 熱, 耐硝酸坫, 高焗, ポゾラ } \\
\text { ンセメント (ASTM I, II, } \\
\text { III, IV, IS と IP) }\end{array}$ & $\begin{array}{l}\text { “Offshore Rules" 7.2, 7.12, } \\
7.13 \text { に準扰。 }\end{array}$ \\
\hline \multicolumn{2}{|c|}{ 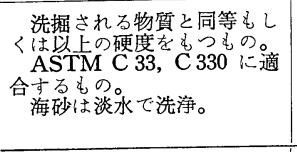 } & \multicolumn{2}{|c|}{$\begin{array}{l}\text { セxントの存在で変質する } \\
\text { もの, セメントと反方す } \\
\text { のは不可。 } \\
\text { 海砂は塩分量, 貝がらの量 } \\
\text { が許容值以でなればな } \\
\text { ない。 }\end{array}$} & \multicolumn{3}{|c|}{$\begin{array}{l}\text { 有害物を含むものは不可。 } \\
\mathrm{SO}_{3} \text { 化合物は } 0.1 \% \text { 以下。 } \\
\text { 不純物 (粘土)は } 2 \% \text { 以下。 }\end{array}$} & $\begin{array}{l}\text { 十分な強度, 耐久性, 適正 } \\
\text { 粒度のむの。 } \\
\text { 化学反応を生ずるもの, 有 } \\
\text { 害物を含むものは不可。 }\end{array}$ & “Offshore Rules”に準抛。 \\
\hline \multicolumn{2}{|c|}{ 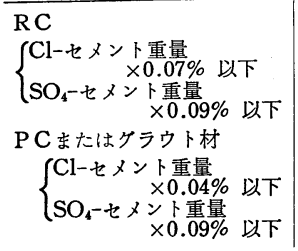 } & \multicolumn{2}{|c|}{ 海水を使用してはならない。 } & \multicolumn{3}{|c|}{$\begin{array}{l}\text { 塩分 } 2 \mathrm{~g} / l \text { 以下 } \\
\text { 飲料水なみの水質 }\end{array}$} & 污濁物の含有は不可。 & “Offshore Rules”に準拠。 \\
\hline
\end{tabular}

Vol. 19, No. 3, March 1981 


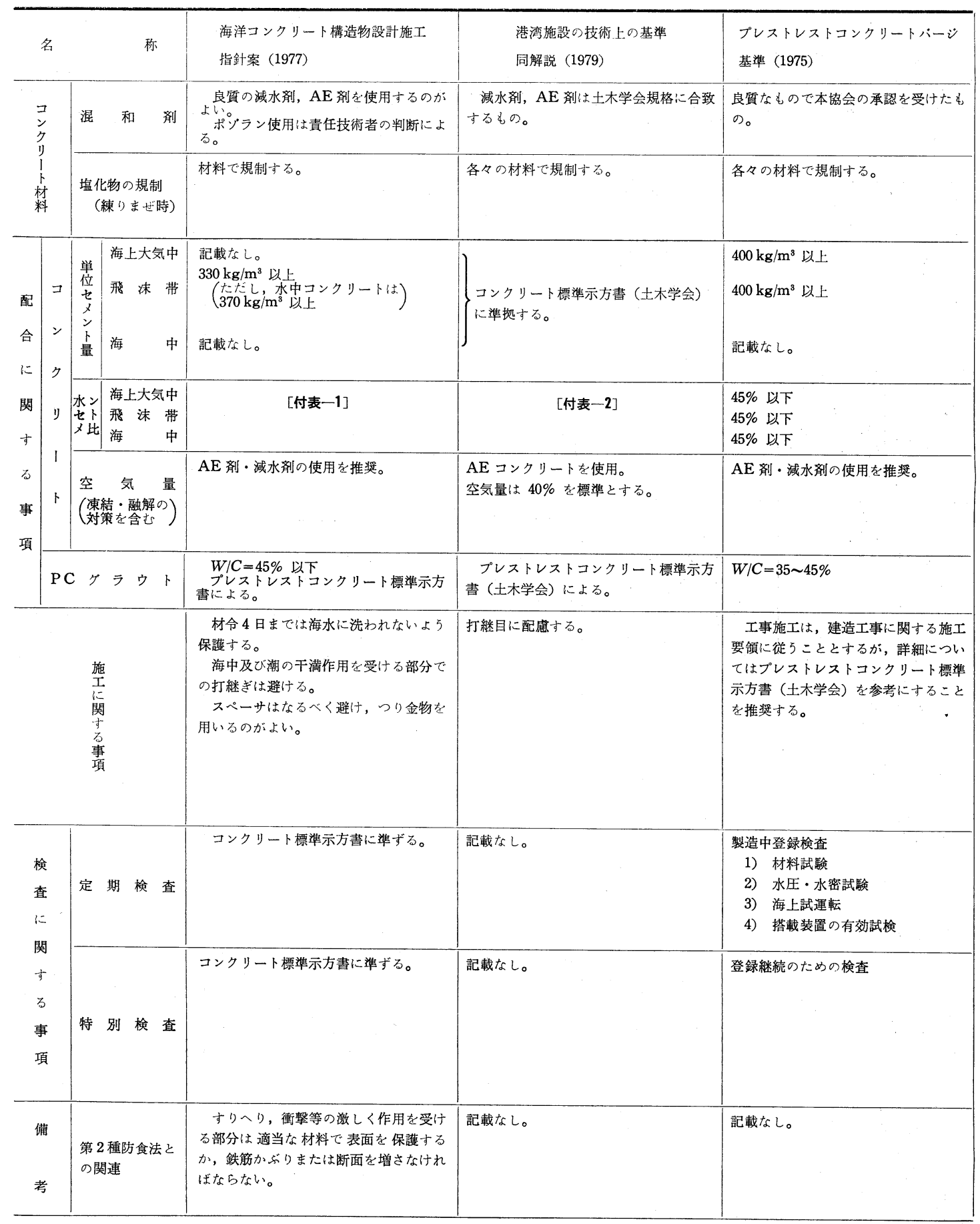

注 1) スターラップは厚さ $50 \mathrm{~cm}$ 以上の部材の場合の值から $13 \mathrm{~mm}$ を引いた值以上。

注 2) a）骨材最大寸法の 1.5 倍

b) 鉄筋最大寸法の 1.5 倍

c) $20 \mathrm{~mm}$ 以上

注 3) “Offshore Rules”は Rules for the Design, Construction and Inspection of Offshore Structures (1977) を示す。 


\begin{tabular}{|c|c|c|c|c|}
\hline $\begin{array}{l}\text { Guide for the Design and } \\
\text { Construction of Fixed } \\
\text { Offshore Concrete Struc- } \\
\text { ture (1978) }\end{array}$ & $\begin{array}{l}\text { Recommendations for the } \\
\text { Design and Construction } \\
\text { of Concrete Sea Structures } \\
\text { (1977) }\end{array}$ & $\begin{array}{l}\text { Rules and Regulations } \\
\text { for the Construction and } \\
\text { Classification of Off. } \\
\text { shore Platforms (1975) }\end{array}$ & $\begin{array}{l}\text { Rules for the Design, } \\
\text { Construction and Inspec- } \\
\text { tion of Offshore Structures } \\
(1977)\end{array}$ & $\begin{array}{l}\text { Guidelines for the Design, } \\
\text { Construction and Clas- } \\
\text { sification of Floating Con- } \\
\text { crete Structures (1978) }\end{array}$ \\
\hline $\begin{array}{l}\text { ポゾランは試験結果を見て使 } \\
\text { 用。 }\end{array}$ & 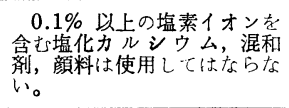 & 塩分な含んではならない。 & 本協会の承認が必要。 & “Offshore Rules”に準拠。 \\
\hline $\begin{aligned} \mathrm{RC}: \mathrm{Cl}-\text { セメント重量 } & \\
& \times 0.10 \% \text { 以下 } \\
\mathrm{PC}: \mathrm{Cl} \text {-セメント重量 } & \\
& \times 0.06 \% \text { 以下 }\end{aligned}$ & 各々の材料で規制する。 & 各々の材料で規制する。 & $\mathrm{CaCl}_{2}$ の使用禁止。 & “Offshore Rules” 準找。 \\
\hline 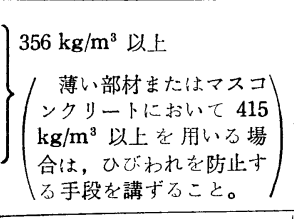 & 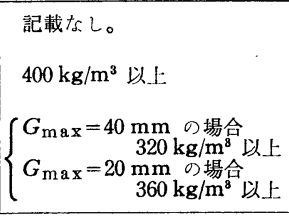 & $\left\{\begin{array}{l}350 \mathrm{~kg} / \mathrm{m}^{3} \text { 以上 } \\
\left(400 \mathrm{~kg} / \mathrm{m}^{3} \text { が望屯しい。 }\right)\end{array}\right.$ & $\begin{array}{l}300 \mathrm{~kg} / \mathrm{m}^{3} \text { 以上: } \\
400 \mathrm{~kg} / \mathrm{m}^{3} \text { 以上: } \\
\text { 記載 } / \text { し。 }\end{array}$ & $\begin{array}{l}\text { “Offshore Rules”に準拠。 } \\
\text { “Offshore Rules”に準拋。 } \\
\text { 記載なっ。 }\end{array}$ \\
\hline $\begin{array}{l}45 \% \text { 以下 } \\
40 \% \text { 以下 } \\
40 \% \text { 以下 }\end{array}$ & $40 \% \sim 45 \%$ & $\begin{array}{l}45 \% \text { 以下 } \\
45 \% \text { 以下 } \\
45 \% \text { 以下 }\end{array}$ & $\begin{array}{l}40 \% \text { 以下が望ましい。 } \\
\text { 最大 } 45 \%\end{array}$ & $\begin{array}{l}\text { “Offshore Rules”に準㧋。 } \\
\text { “Offshore Rules”に準扙。 } \\
\text { “Offshore Rules”に準扴。 }\end{array}$ \\
\hline $\begin{array}{l}\text { 凍結・融解の対策が必要な } \\
\text { 場合は ACI 201, 2 R-78 } \\
\text { 規定。 }\end{array}$ & $\begin{array}{l}\text { 10〜 } 40 \mathrm{~mm} \text { の最大寸法の } \\
\text { 骨材で } 4 \text { 7\%。 } \\
\text { ただし, 気泡径の分布, 気 } \\
\text { 泡間隔については注意するこ } \\
\text { と。 }\end{array}$ & 記載なし。 & 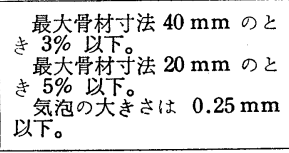 & “Offshore Rules”に準扴。 \\
\hline $\begin{array}{l}\text { ACI 318-77, 16〜18 項に } \\
\text { 適合するもの。 }\end{array}$ & $\begin{array}{l}\text { 全膨張率 } 10 \% \text { 以下。 } \\
\text { 海水の使用を禁止。 }\end{array}$ & $\begin{array}{l}\text { 压縮強度が } 306 \mathrm{~kg} / \mathrm{cm}^{2} \\
\text { 以上。 } \\
\text { 粘度 } 2800 \mu / \mathrm{m}\end{array}$ & $\begin{array}{l}\text { 压縮狙度 } 300 \mathrm{~kg} / \mathrm{cm}^{2} \text { 以上 } \\
\mathrm{Cl}: C \times 05 \% \text { 以下 } \\
\text { 全膨張率 } 10 \% \text { 以下 }\end{array}$ & “Offshore Rules” に準敃。 \\
\hline $\begin{array}{l}\text { 水密性を要する部材の打継 } \\
\text { 目は, } \\
\text { 1) 粗骨材はをの平均径の } \\
25 \% \text { が現われるように } \\
\text { 処理する。 } \\
\text { 2) エポキン樹脂接着剤を } \\
\text { 塗布する。 } \\
\text { 3）打継目付近のコンクリ } \\
\text { ートはセメント量を多く } \\
\text { する。 } \\
\end{array}$ & $\begin{array}{l}\text { 打継き， 水和による温度上 } \\
\text { 昇, 寒中施工, 養生等につい } \\
\text { て概念在規定している。 }\end{array}$ & $\begin{array}{l}\text { 金属及びプラスチックス } \\
\text { ペーサの使用を禁止する。 } \\
\text { ショイントの施エを配虑 } \\
\text { ナる(数種類の案を提示し } \\
\text { ている)。 }\end{array}$ & $\begin{array}{c}\text { セメントの始発前に打設。 } \\
\text { (省略) }\end{array}$ & $\begin{array}{l}\text { 鉄筋配置位置及びPC鋼棒 } \\
\text { 配置位置に関しては } \\
\text { “Offshore Rules”に従う。 }\end{array}$ \\
\hline 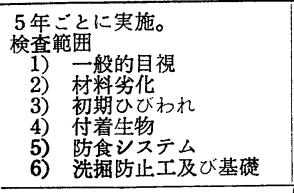 & $\begin{array}{l}\text { 定期的に実施。 } \\
\text { 検查筬梊沫部, 修理部 } \\
\text { 検查範国 } \\
\text { 1) 般的目視 } \\
\text { 2) 材料劣化 } \\
\text { 3) ひひわれ } \\
\text { 4) 鉄筋電位測定 }\end{array}$ & 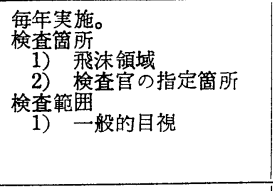 & $\begin{array}{l}\text { 5年以内で実施。 } \\
\text { 検查範囲般的目視 } \\
\text { 1) } \\
\text { 2) 材料劣华 } \\
\text { 3) 初期びわれ } \\
\text { 4) 防食さステム } \\
\text { 5) 付着生物 } \\
\text { 6) 堆 砂 }\end{array}$ & $\begin{array}{l}2 \text { 年ごとに実施 } \\
\text { 検查範囲 } \\
\text { 1）ひびわれ } \\
\text { 2）コンクリートの劣化 } \\
\text { 3）鉄筋の腐食 }\end{array}$ \\
\hline $\begin{array}{l}\text { 事故・損傷・劣化の発見時 } \\
\text { 構造物の安定に影響する部 } \\
\text { 材に変更がある場合。 } \\
\text { 諸条件の変更時 }\end{array}$ & 記載なし。 & $\begin{array}{l}\quad 4 \text { 年ごと船級更新時に実 } \\
\text { 施。 } \\
\text { 検查箇所 } \\
\text { 1）飛沫領域 } \\
\text { 2）䒾置・設備 }\end{array}$ & $\begin{array}{l}\text { 事故や損傷劣化の発見時 } \\
\text { 本協会への検查箇所の通知 }\end{array}$ & 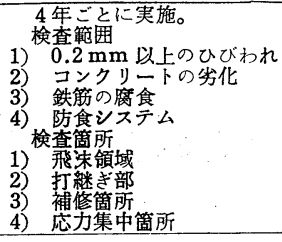 \\
\hline 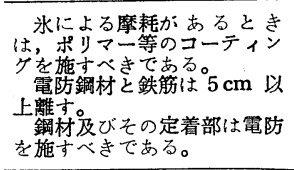 & $\begin{array}{l}\text { かぶりへのポリマー含漫や } \\
\text { 永久的なコーティング等の特 } \\
\text { 別な防食が施される場合は, } \\
\text { かぶりの規定を緩和できる。 }\end{array}$ & 記載なし。 & $\begin{array}{l}\text { コーティンケ，亜鉛めっ } \\
\text { き, 陰極防食は可。 } \\
\text { 異質のPC鋼材の使用は電 } \\
\text { 食を起こす可能性があるのて } \\
\text { 不可。 }\end{array}$ & “Offshore Rules”に準挟。 \\
\hline
\end{tabular}


[付表-1]

（1）凍結嫄解がしばしば繰り返さ れる地域

\begin{tabular}{|c|c|c|c|}
\hline $\begin{array}{l}\text { 構造物 } \\
\text { の露出 } \\
\text { 状態 }\end{array}$ & | 薄 & $\begin{array}{l}\text { 普通。 } \\
\text { 場 合 }\end{array}$ & 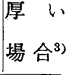 \\
\hline $\begin{array}{l}\text { a ) 潮風を受ける } \\
\text { 部分，波しん゙き } \\
\text { を受ける部分 }\end{array}$ & 50 & 55 & 55 \\
\hline $\begin{array}{l}\text { b) 潮の干満作用 } \\
\text { を受ける部分, } \\
\text { 海永で洗われる } \\
\text { 部分 }\end{array}$ & 45 & 50 & 55 \\
\hline $\begin{array}{l}\text { c）常時海中にあ } \\
\text { る部分 }\end{array}$ & 55 & 60 & 65 \\
\hline
\end{tabular}

1）断面の厚さが $20 \mathrm{~cm}$ 程度以下の構造の部分

2）1）及び 3）に属さない部分

3）マッシフなな構造物の表面部分

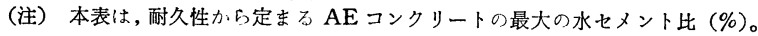

[付表-2]

（2）氷点下の気温となることがま れな地域

\begin{tabular}{|c|c|c|c|}
\hline $\begin{array}{l}\text { 構造物 } \\
\text { の露出出態 }\end{array}$ & & & \\
\hline 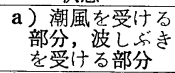 & 50 & 60 & 65 \\
\hline $\begin{array}{l}\text { b) 潮の干满作用 } \\
\text { を受ける部分, } \\
\text { 海永で洗われる } \\
\text { 部分 }\end{array}$ & 45 & 50 & 55 \\
\hline $\begin{array}{l}\text { c) 常時海中にむ } \\
\text { る部分 }\end{array}$ & 55 & 60 & 65 \\
\hline
\end{tabular}

部分
最大水セメント比 $(\%)$

\begin{tabular}{|c|c|c|}
\hline 構造部材 & $\begin{array}{l}\text { 凍結融解 } \\
\text { を受ける } \\
\text { 地域 }\end{array}$ & $\begin{array}{l}\text { 凍結融解 } \\
\text { 受けな } \\
\text { い地域 }\end{array}$ \\
\hline $\begin{array}{l}\text { 係 留 直 柱, } \\
\text { 基 礎, 胸 壁 }\end{array}$ & 60 & 65 \\
\hline 係船岸上部工 & 60 & 65 \\
\hline $\begin{array}{l}\text { ケーソン, ウェ } \\
\text { ル, セルラー, } \\
\text { L形 }\end{array}$ & 55 & 55 \\
\hline 控 & 60 & 60 \\
\hline
\end{tabular}

表一6 第 2 種防食法に関する規格基準

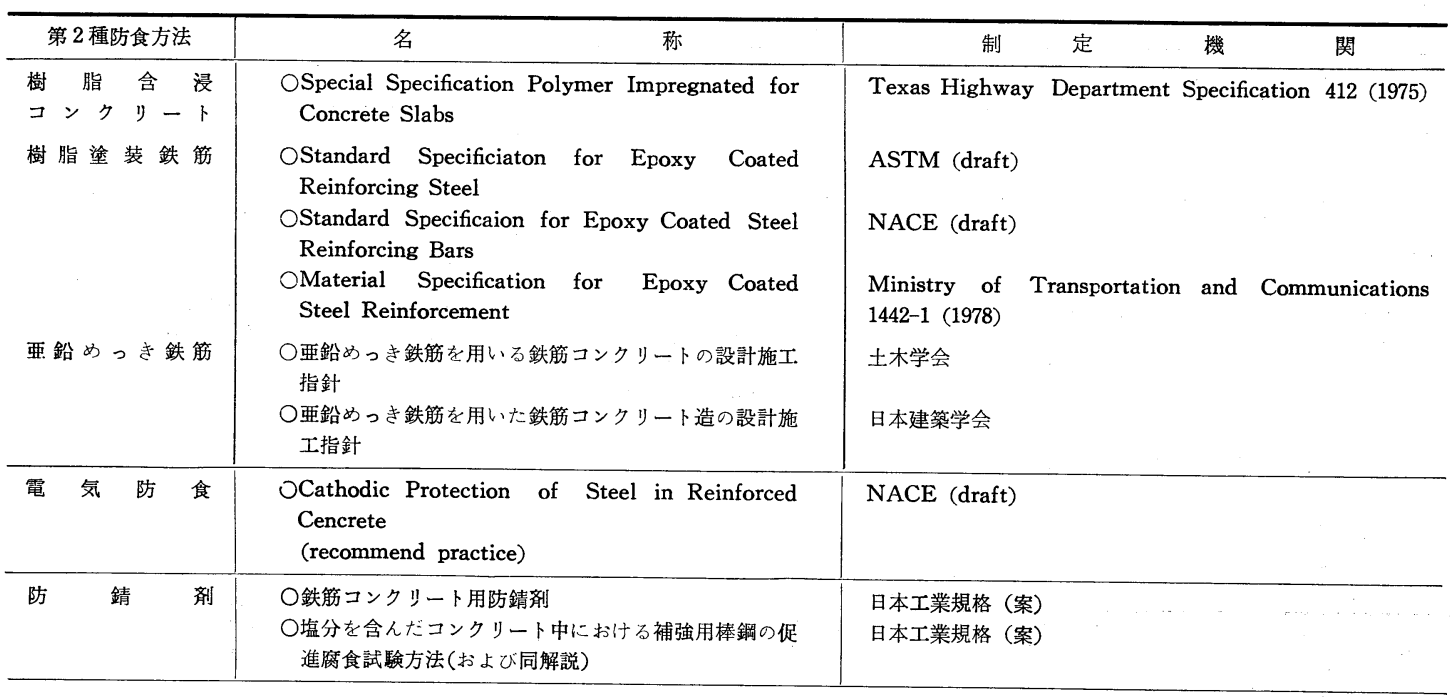

\section{国除会識ニュース}

\section{プラスチックスの建設材料並びに建築物への応用 IPC/RILEM/IBK, International Symposium 1981 Prague, "Plastics in Material and Structural Engineering"}

1. 主 催: ICP / RILEM /IBK

2. 期日: 1981 年 6 月 $23 \sim 25$ 日

3. 場 所 : チェコスロバキア・プラハ市

4. 問合せ先 : ICP : RILEM/IBK International
Symposium 1981 Prague, Secretariat, c/o Dum techniky Cs. VTS, Gorkeho nam.

23, Prague 1, 11282 Czechoslovakia 